\title{
LABORATORY SAFETY FOR SCIENCE TEACHERS
}

\section{Editors}

Simge KOC

Bülent CAVAS 


\section{(๑) Copyright 2020}

Printing, broadcasting and sales rights of this book are reserved to Akademisyen Publishing House Inc. All or parts of this book may not be reproduced, printed or distributed by any means mechanical, electronic, photocopying, magnetic paper and/ or other methods without prior written permission of the publisher. Tables, figures and graphics cannot be used for commercial purposes without permission.

This book is sold with banderol of Republic of Turkey Ministry of Culture.

ISBN

978-625-779-518-0

\section{Book Title}

Laboratory Safety For Science Teachers

\section{Editors}

Simge KOÇ

Bülent ÇAVAŞ

\section{Publishing Coordinator \\ Yasin Dilmen}

Page and Cover Design

Typesetting and Cover Desing by Akademisyen

Publisher Certificate Number

47518

Printing and Binding

Printing press Vadi

Bisac Code

EDU053000

DOI

10.37609/akya.821

\section{GENEL DAĞITIM}

\section{Akademisyen Kitabevi A.Ș.}

Halk Sokak 5/ A

Yenişehir / Ankara

Tel: 03124311633

siparis@akademisyen.com

\section{www . akademis y en.com}




\section{PREFACE}

The world is getting more complex and it is getting harder to answer questions in a simple way. Experimental designs based on hands on activities have been gained much more importance on science education which is combined with technology, engineering and math. According to the developments and discoveries in science field, new experimental designs, elements and chemical reactions have been involved in practical applications. Today's technological progress has authorized us to gather and endorse information with an increasing speed; it has also permitted us to make experiments more like real-world science.

This guideline can be helpful to support safer working areas in laboratories for not only science teachers it can be useful also for supervisors, administrators and the other science curriculum directors. One of the priorities is to have an understanding of a science teachers' mission and school science safety regulations and also make teachers and authorities aware about the high frequency of school science laboratory accidents.Laboratories are visibly more dangerous areas than the class environment at schools. For an example, students can break glassware materials and use the tools with incorrect interactions. These accidents sometimes may cause simple cuts or injury but may be sometimes it may cause severe burns and serious injuries. Therefore it needs to have some arrangements and educational interventions that can minimize the damages by conscious interventions against such accidents. By the issues have been involved in this guidelines will help to create a safer learning environment. Transformation of a classroom to a laboratory, safe storage of chemicals, planning the science activities in the laboratory, electrical and fire safety, ventilation and use of fume cupboards, use of eye wash and safety shower, use of heat sources, emergency exit doors, seismic movements, distribution of science curriculum subjects in terms of laboratory use, order and cleaning in laboratory and pictograms are the relevant topics that will help a science teacher to have more awareness on safety.

The manual about "Laboratory Safety for Science Teachers" created with the support of sources believed to be reliable and known as the bests in the field. The aim is to generate a general source for science teachers for daily practices at school laboratories. It is intended to decrease the accidental risks according to the usage of school science laboratories.

Special thanks to Sema Ünal and Ayşegül Çaka for Charcoal Drawing Designs. 


\section{ABBREVIATIONS}

ANSI: American National Standarts Institute

CSSS: $\quad$ Council of State Science Supervisors

GHS: $\quad$ Globally Harmonized System

HCS: $\quad$ Hazard Communication Standard

MoNE: $\quad$ Ministry of National Education

NFPA: National Fire Protection Association

NRC: $\quad$ National Research Council

NSES: $\quad$ National Science Education Standards

NSTA: National Science Teachers Association

OSHA: Occupational Safety and Health Administration 


\section{CONTENTS}

\section{CHAPTER 1}

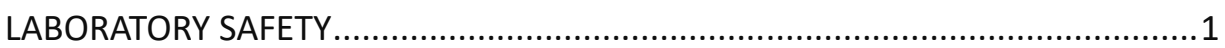

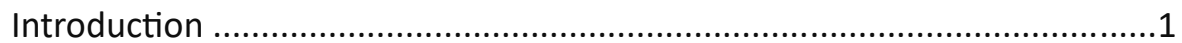

Dimensions of Laboratory Safety Procedure ………....................................

Creating a Safe Learning Environment ..................................................6

Enough Space to Work in Safely ..............................................................

Transformation of a Classroom to a Laboratory ...........................................9

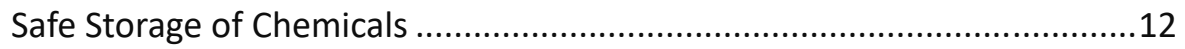

Planning the Science Activities in the Laboratory ....................................13

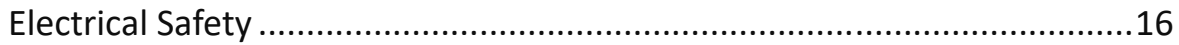

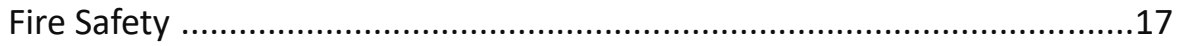

Ventilation and Use of Fume Cupboards .................................................18

Use of Eye Wash and Safety Shower ........................................................19

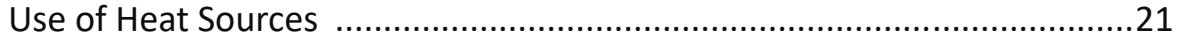

Emergency Exit Doors in the Laboratory .................................................22

Seismic Movements Affecting Safety in Laboratory .................................22

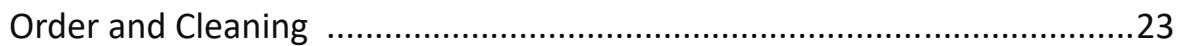

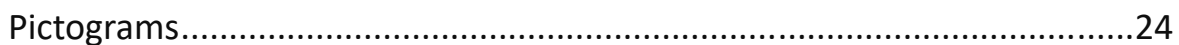

\section{CHAPTER 2}

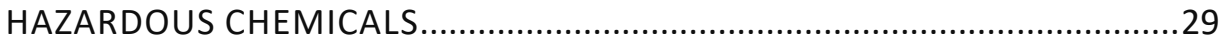

CHAPTER 3

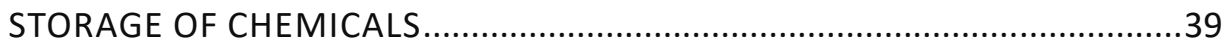

CHAPTER 4

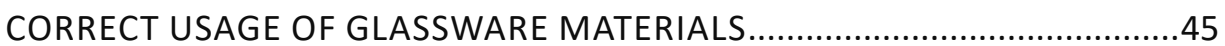




\section{CHAPTER 5}

ACCIDENTS CAUSED BY FIRE.

\section{CHAPTER 6}

ACCIDENTS CAUSED BY ELECTRICAL PROBLEMS.

\section{CHAPTER 7}

SAFETY PROTECTIONS

CHAPTER 8

PATHOGENS

CHAPTER 9

FIRST AID 


\section{REFERENCES}

Ajaja, P. (2009). Evaluation of science teaching in secondary schools in delta state 2-teaching of the sciences. International Journal Educational Sciences, 1(2), 119-129.

American National Standards Institute. (1990). Emergency eyewash and shower equipment. New York: Author

Council of State Science Supervisors. (2000). Science \& safety:Making the connection. Virginia: Author Retrieved from http://www.csss.enc.org with full text from-ERIC-ED449028

Downs, G. E., \& Gerlovich, J. L. (1983). Science safety for elementary teachers. Ames, Iowa: The Iowa State University Press.

Emik, C. (2011). Yatılı ilköğretim bölge okullarındaki fen ve teknoloji laboratuvarlarının durumu (Master's thesis). Gazi University, Institute of Educational Sciences, Ankara, Turkey.

Erol, F. (2009). Okulda güvenlik sorununa yol açan etkenlerin belirlenmesi. Ankara, Turkey: EARGED Ministry of National Education Book Series. Retrieved from

https://www.meb.gov.tr/earged/earged/Okul_guvenligi.pdf

Erol, M., Demir, S., \& Böyük, U., (2010). Modular mobile training: developing a program on science and technology experiments. Proceedings of the $7^{\text {th }}$ International Conference on Hands-on Science (pp.450). Greece.

Hamurcu, H. (1998). Fen derslerinde güvenlik. Hacettepe University Journal of Education, 14, 29-32. Retrieved from

http://www.efdergi.hacettepe.edu.tr/yonetim/icerik/makaleler/1158-published.pdf

Hofstein, A., Navon, O., Kipnis, M., \& Mamlok-Naaman, R. (2005). Developing students' ability to ask more and better questions resulting from inquiry-type chemistry laboratories. Journal of Research in Science Teaching, 42(7), 791-806.

Karal, D. (2011). Korkmadan öğrenmek: Okul ve okul çevresi güvenliği. International Strategic Research Organization (USAK).

Keller, J. J. \& Associates, Inc. (2012). HAZCOM Made Easier What You Need to Know about Hazard Communication \& GHS. USA.

Keskin, A. (2010). İlköğretim fen öğretiminde laboratuvar kullanımının öğrencilerin bilimsel süreç beceri gelişimlerine etkisi (Master’s thesis). Yüzüncü Yll University, Institute of Social Sciences, Van.

Motz, L. L., Biehle, J. T. \& West, S. S. (2007). NSTA Guide to Planning School Science Facilities (2 ${ }^{\text {nd }}$ ed). Arlington, VA: NSTA Press.

National Fire Protection Association (NFPA), (2004). NFPA 45 standard on fire protection for laboratories using chemicals. Quincy, MA: Author

National Research Council (NRC), (2005). National science education standards. Washington, DC: National Academy Press.

National Science Teachers Association (NSTA), (2007). Safety and school science instruction. Arlington, VA: NSTA Press.

Occupational Safety and Health Administration (OSHA), (1997). Small entity compliance guide for OSHA's abatement verification regulation (29 CFR 1903.19). USA: Department of Labor. Retrieved from: https://www.osha.gov/

Ministry of National Education (MoNE), (2013). İlköğretim Kurumları (İlkokullar ve Ortaokullar) Fen Bilimleri Dersi (3, 4, 5, 6, 7 ve 8. Sinıflar) Öğretim Programı. Ankara: MEB Yayınevi.

Ministry of National Education (MoNE), (2015). Educational Structures Minimum Design Standards Guide. Ankara: Devlet Kitapları Müdürlüğü Basım Evi.

Tekin, N. (2020). Covid-19 infection experience of a family phycisian in turkey. Turkish Journal of Family Medicine and Primary Care, 14 (2): 166-170.

Texley, J., Kwan, T. \& Summers, J. (2004). Investigating safely: a guide for high school teachers. Arlington, VA: NSTA Press. 
West, S. 1999. Lab Safety. The Science Teacher. 58 (9): 45-51.

West, S., Westerlund, S., Stephenson, A. \& Nelson, N. (2003). Conditions that affect secondary science safety: Results from 2001 texas survey, overcrowding. The Texas Science Teacher, 32 (2).

Yılmaz, A., Uludağ, N. \& Morgil, İ. (2001). Basic knowledge of university students on the organic chemistry laboratory techniques, efficiency of application and suggestions. Hacettepe University Journal of Education, 21, 151-157.

Young, J. A. (Ed.). (1991). Improving Safety in the Chemical Laboratory: A Practical Guide (2nd ed.). USA: Wiley Interscience Publication.

INTERNET REFERENCES:

1. https://www.osha.gov/dsg/hazcom/ghs.html

2. http://www.msdsonline.com/resources/ghs-answer-center/10-ghs-facts-in-60-seconds

3. http://www.unece.org/trans/danger/publi/ghs/implementation_e.html

4. https://www.freepik.com/free-photos-vectors/arrow

5. http://chemlabs.uoregon.edu/Safety/NFPA_White.html|title=More on white codes 